\title{
Survivorship of juvenile surf clams Donax serra (Bivalvia, Donacidae) exposed to severe hypoxia and hydrogen sulphide
}

\author{
J. Laudien ${ }^{\text {a,* }}$, D. Schiedek ${ }^{\text {b }}$ T. Brey ${ }^{\text {a }}$, H.-O. Pörtner ${ }^{\text {a }}$, W.E. Arntz ${ }^{\mathrm{a}}$ \\ alfred Wegener Institute for Polar and Marine Research, P.O. Box 120161, 27515 Bremerhaven, Germany \\ ${ }^{\mathrm{b}}$ Baltic Sea Research Institute, Warnemünde, Germany
}

Received 31 October 2001; received in revised form 8 January 2002; accepted 28 January 2002

\begin{abstract}
Toxic "sulphide eruptions" sporadically occur in the highly productive inshore regions of the central Namibian Benguela upwelling system. The surf clam Donax serra (Röding, 1798) dominates the intertidal and upper subtidal of large exposed sandy beaches of southern Africa and its recruitment seems to be affected by sulphide events. The reaction of juvenile surf clams to low oxygen concentrations and sulphide occurrence $\left(0.1 \mathrm{mmol}^{-1}\right)$ was examined by in vitro exposure experiments in a gas-tight continuous flow system. After $2 \mathrm{~h}$ of hypoxic- and hypoxic/sulphidic conditions, clams moved to the sediment surface, aiding their passive transport to areas with more favourable conditions. The clams showed a high sulphide detoxification capacity by oxidising the penetrating hydrogen sulphide to non-toxic thiosulphate. Moreover, juvenile $D$. serra switched to anaerobic energy production, indicated by the significant accumulation of succinate and, to some extent, alanine. Test animals were not able to reduce their energy requirements enough to withstand long periods of exposure, leading to a median survival time $\left(\mathrm{LT}_{50}\right)$ of $80 \mathrm{~h}$ under hypoxic sulphide incubation. In conclusion, natural "sulphide eruptions", especially those with a large spatial and temporal extension, have to be considered as an important factor for D. serra recruitment failures. Hydrogen sulphide is assumed to be a potential community structuring factor. (C) 2002 Elsevier Science B.V. All rights reserved.
\end{abstract}

Keywords: Benguela upwelling system; Donax serra; Hydrogen sulphide; Hypoxia; Succinate; Sulphide oxidation; Thiosulphate

\footnotetext{
* Corresponding author. Tel.: +49-471-4831-1643; fax: +49-471-4831-1149.

E-mail address: jlaudien@awi-bremerhaven.de (J. Laudien).
} 


\section{Introduction}

Coastal upwelling regions are frequently exposed to hypoxic conditions (Rosenberg et al., 1983; Arntz et al., 1991; Tarazona et al., 1991; Diaz and Rosenberg, 1995; Gallardo et al., 1998) owing to extremely high primary production and subsequent oxidative degeneration of organic matter (Van der Plas, 1999; Fossing et al., 2000), Advancing hypoxic water has the potential to cause mass mortalities of benthos and fish (Brongersma-Sanders, 1957; Hart and Currie, 1960; Arntz, 1981). Further anaerobic degradation of organic matter due to sulphate reducing bacteria results in the production of hydrogen sulphide (e.g., Huxtable, 1986; Widdel, 1988; Jørgensen, 1990). For the Benguela upwelling system permanent hypoxic conditions are recorded in the inshore areas downstream of the major upwelling centres (Bailey, 1991, 1999; Fossing et al., 2000). Especially in summer, a combination of physical and biochemical processes causes sulphidic water to rise sporadically to the surface during "sulphide eruptions" (Bailey, 1991). As a consequence, extremely low oxygen concentrations and high hydrogen sulphide concentrations are occasionally recorded in the intertidal and upper subtidal (Currie, 1999). The impact is perpetual as hydrogen sulphide has a half-life of a few hours even in oxygen-saturated seawater (Morse et al., 1987).

Many benthic organisms live in environments with regular occurrence of hypoxia and hydrogen sulphide. Hydrogen sulphide is highly toxic in nanomolar concentrations to aerobic eukaryotic organisms (Evans, 1967; Nicholls, 1975; National Research Council, 1979). Most intertidal bivalves are capable of sustaining their energy production by the use of anaerobic pathways (reviews: De Zwaan, 1977; Storey and Storey, 1990; Grieshaber et al., 1994). Furthermore, they have evolved a detoxification strategy by oxidising the poisonous hydrogen sulphide to non-toxic compounds, mainly thiosulphate (Jahn and Theede, 1997; Jahn et al., 1997). However, there is extensive evidence for stressful and harmful effects of hypoxia and anoxia from both in situ and laboratory experiments (review: Diaz and Rosenberg, 1995). These effects are even more pronounced in the presence of hydrogen sulphide (National Research Council, 1979; Shumway et al., 1983; Diaz and Rosenberg, 1995; Jahn and Theede, 1997).

Ecophysiological studies concerning hypoxia and occurrence of hydrogen sulphide are almost entirely devoted to species from hydrothermal vents or from eutrophicated coastal areas of the Northern Hemisphere. At present, not much is known about the metabolic effects of naturally occurring hydrogen sulphide on macrobenthic species in a coastal upwelling ecosystem such as the Benguela. The surf clam Donax serra (Röding, 1798) dominates the intertidal and upper subtidal of large exposed sandy beaches of southern Africa and was affected by sulphide events (Bailey, 1999). Laudien et al. (in press) hypothesised that an observed $D$. serra recruitment failure could have resulted from the occurrence of hypoxia and hydrogen sulphide affecting meroplanktic larvae and early juvenile survivorship. Therefore, the objectives of the present study were: (i) to investigate how juvenile $D$. serra deal with severe hypoxia and sulphide exposure $\left(100 \mu \mathrm{mol} 1^{-1}\right)$ and (ii) to investigate as to what extent juvenile D. serra are able to detoxify this poisonous compound. 


\section{Material and methods}

\subsection{Study area and sampling}

D. serra was collected during low tide in the intertidal of an exposed Namibian sandy beach (Langstrand: $22^{\circ} 47^{\prime} \mathrm{S}, 14^{\circ} 33^{\prime} \mathrm{E}$ ), which is impacted by continuous wave action. The area is subjected to subequal semi-diurnal micro- to macrotides with a maximum range of about $2 \mathrm{~m}$ (McLachlan, 1986). The study site is described by Laudien et al. (in press) and main features of the beach are summarised in McLachlan (1985).

During a recruitment event in November and December 1999, post-settled D. serra of the smallest cohort (2-6 mm anterior-posterior length, approx. $5.5 \mathrm{mg}$ ) were collected by gently sieving the sediment $(1 \mathrm{~mm}$ mesh). Within $1 \mathrm{~h}$ after sampling, animals were transported to the laboratory (burrowed in wet sand) and transferred into the experimental chambers. Experiments were started after $3 \mathrm{~h}$.

\subsection{Experiments}

\subsubsection{Tolerance of severe hypoxia and sulphide}

Survivorship of juvenile $D$. serra was investigated in vitro under normoxic and hypoxic conditions in (i) the absence and (ii) the presence of hydrogen sulphide using a gas-tight system with continuous flow of seawater from a refillable reservoir (Fig. 1). The water reservoir $(\mathrm{R} 1)$ contained 701 of seawater $(\mathrm{S}=35)$ filtered twice (National aquarium filter system and paper filter Whatman 2V). For deoxygenation of the water to a minimum oxygen content, it was warmed to $30-35{ }^{\circ} \mathrm{C}$ with an external red light, bubbled with pure nitrogen gas for $4 \mathrm{~h}$ and then cooled to room temperature. Deoxygenation was confirmed titrometrically (Grasshoff et al., 1983). Six single 250$\mathrm{ml}$ filter flasks $(\mathrm{F})$ containing a sand layer $(100 \mathrm{ml}$ of sand from the natural habitat, sterilized at $700{ }^{\circ} \mathrm{C}$ then cooled) were connected to the reservoir with oxygen impermeable Viton tubes. One juvenile D. serra was introduced into each filter flask before it was closed gas-tight with a rubber plug. This experiment was repeated four times using always a new individual.

At the beginning of each incubation period, all filter flasks were filled completely and kept at $16 \pm 0.5{ }^{\circ} \mathrm{C}$. Flow rate through each filter flask was set to $250 \mathrm{ml} \mathrm{h}^{-1}$ with variable clamp valves (CV). Due to varying water level in R1 causing changes in hydrostatic pressure, the flow rate was controlled and readjusted when necessary every $2 \mathrm{~h}$. The volume of the effluent water of R1 was replaced continuously by overlaying pure nitrogen, and excessive gas could exhaust through a valve (V). Viton tubes (VT) were connected to glass tubes (GT), which were plunged through gas-tight plugs (P) of the filter flasks. The openings of the glass tubes were placed in the sand approx. $5 \mathrm{~mm}$ above the flask bottom. Inflowing water replaced the water in the filter flasks, which drained out through glass capillaries (C). A similar reservoir (R2) placed above the first one was set-up in order to be able to prepare new hypoxic water and refill R1. Again, the outflowing volume was replaced by pure nitrogen gas. In addition hypoxic and aerated normoxic controls were set up. In total, 72 clams were tested, 24 under 


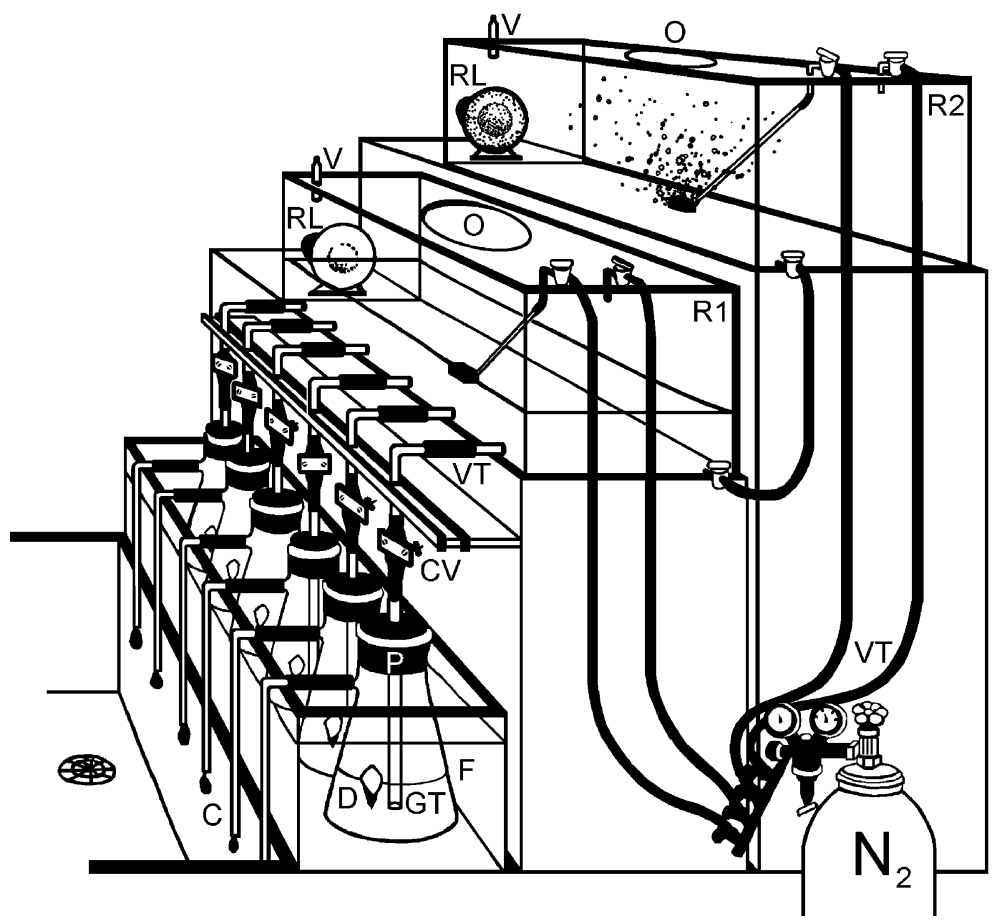

Fig. 1. Gas-tight system flow-through system $\mathrm{C}=$ glass capillaries, $\mathrm{CV}=$ clamp valve, $\mathrm{F}=$ filter flask, $\mathrm{GT}=\mathrm{glass}$ tube, $\mathrm{N}=$ nitrogen gas, $\mathrm{O}=$ closable opening, $\mathrm{P}=$ gas-tight plugs, $\mathrm{R} 1=$ water reservoir 1 , $\mathrm{R} 2$ = water reservoir 2 , $\mathrm{RL}=$ redlight, $\mathrm{V}=$ valve, $\mathrm{VT}=$ Viton tube.

normoxia, 24 under hypoxic conditions and 24 under hypoxic/sulphidic conditions, respectively.

Stock solution of hydrogen sulphide (approx. $10 \mathrm{mmol}$ ) was prepared by dissolving (aqua bidest-washed) $\mathrm{Na}_{2} \mathrm{~S} \times \mathrm{H}_{2} \mathrm{O}$ crystals $(\chi=7-9)$ in $\mathrm{N}_{2}$-saturated sea-water taken from $\mathrm{R} 1$. Prior to the experiments, the concentration of the stock was determined by iodometric titration (Poethke, 1973) and sulphide was added to R1 through a closeable opening (O) to a final sulphide concentration of $0.1 \mathrm{mmol}^{-1}$. To monitor the sulphide concentration during the course of the incubation, a 50-ml water sample was collected once every $2 \mathrm{~h}$ at the outflow of one glass capillary. Sulphide concentrations were determined spectrophotometrically at $660 \mathrm{~nm}$ according to the methylene blue method (Fonselius, 1976). Whenever R1 was refilled, at the start as well as at the end of the experiment, oxygen concentration in the water was checked titrometrically (Grasshoff et al., 1983). Sulphide did not change the $\mathrm{pH}$ of the incubation medium significantly as confirmed by $\mathrm{pH}$ controls (see also Hahlbeck et al., 2000).

Mortality assessment of test animals was based on failure of the valve closure reflex (Jahn and Theede, 1997) when the gaping surf clams were touched with the glass pipe of the water inlet. The number of surviving bivalves was monitored once every $2 \mathrm{~h}$ over a period of 7 days and mortality is given as median survival time 
$\left(\mathrm{LT}_{50}\right)$ using the probability relation between percent mortality and time (Litchfield, 1949).

\subsubsection{Short-term incubations in the presence of sulphide $\left(0.1 \mathrm{mmol} \mathrm{l}^{-1}\right)$}

Three replicated groups, with six juvenile $D$. serra each, were introduced into the above-described set-up for seven different time periods. In total, 21 groups of test animals (3 replicates $\times 7$ time periods) were investigated. Incubation was terminated after $0,1,3$, $6,12,24$ and $48 \mathrm{~h}$ of exposure. Thereafter the tissues of the test animals were rapidly dissected, blotted dry and the pooled sample of each replicate immediately stored in liquid nitrogen until biochemical analysis.

\subsubsection{Biochemical analyses}

Sulphide oxidation products, e.g. sulphite and thiosulphate were determined in the juvenile surf clams as described in Schiedek et al. (1997): The pooled sample of six shell free juvenile $D$. serra (one replicate; approx. $0.15 \mathrm{~g}$ wet mass) were ground to fine powder in a mortar precooled by liquid nitrogen. Concentrations of sulphite $\left(\mathrm{SO}_{3}{ }^{2-}\right)$, sulphide $\left(\mathrm{H}_{2} \mathrm{~S}\right)$, cystein $\left(\mathrm{C}_{3} \mathrm{H}_{7} \mathrm{NO}_{2} \mathrm{HS}\right)$, thiosulphate $\left(\mathrm{S}_{2} \mathrm{O}_{3}{ }^{2-}\right)$ and glutathione $\left(\mathrm{C}_{20} \mathrm{H}_{32} \mathrm{~N}_{6} \mathrm{O}_{12} \mathrm{~S}_{2}\right)$ were quantified in the tissue by High-Performance Liquid Chromatography (HPLC) after derivatisation with monobromobimane (e.g., Völkel and Grieshaber, 1994; Jahn et al., 1996; Jahn 1997). The content of succinate and of the free amino acids alanine, aspartate and glutamate were measured as indicators for the onset of anaerobiosis. The free amino acids were analysed from perchloric acid (PCA) extracts. A 50-mg portion of the frozen tissue powder was transferred to $0.25 \mathrm{ml} 3 \mathrm{~mol}^{-1} \mathrm{PCA}$ and homogenised with an UltraTurrax for $20 \mathrm{~s}$. After centrifugation $(12 \mathrm{~min}, 12,000 \times \mathrm{g})$, the $\mathrm{pH}$ of the supernatant was neutralised by adding $5 \mathrm{~mol} \mathrm{l}^{-1} \mathrm{~K}_{2} \mathrm{CO}_{3}$, controlled by the colour change of methylorange (1 drop). The precipitate was removed by centrifugation $(20 \mathrm{~min}, 17,000 \times g)$. Amino acids were separated and determined via HPLC (5 $\mu \mathrm{m}$, Superspher 60, 125-4, RP-8, MERCK) according to Schiedek (1997). Succinate was analysed via capillary electrophoresis according to a modified method after "Agilent" (Organic Acid Analysis Kit P/N 5063-6510) (T. Hirse and H.-O. Pörtner, unpublished). Trichloric acetic acid (TCA) extracts were prepared using TCA (15\%) and $0.12 \mathrm{~g} \mathrm{l}^{-1}$ tatrate as an internal standard. Frozen tissue powder $(100 \mathrm{mg})$ was suspended in the 3.5 -fold volume of cold TCA and homogenised with an Ultra-Turrax for $10 \mathrm{~s}$. After centrifugation $\left(3 \mathrm{~min}, 16,000 \times g, 0{ }^{\circ} \mathrm{C}\right)$ the supernatant was neutralised by the 3 -fold volume of 1:4 $n$-Octylamine: 1,1,2Trichlortrifluorethan (Freon), mixed and centrifuged (1 min, 16,000 $\times g, 0{ }^{\circ} \mathrm{C}$ ). The upper phase was stored at $-80{ }^{\circ} \mathrm{C}$ and diluted $1: 4$ and filtered through a $0.2-\mu \mathrm{m}$ injection filter prior to analyses. Succinate was separated with a "eCAP Capillary Tubing" (75 $\mu \mathrm{m}$, $120 \mathrm{~cm}$, Beckman 338473) at $27 \mathrm{kV}$ and $15{ }^{\circ} \mathrm{C}$ and detected (PDA) at $214 \mathrm{~nm}$. The separating buffer consisted of 1/5/20 Brij 35 (Fluka)/Acetonitril (Riedel, chromasolv)/ Organic Acid Buffer (Agilent).

\subsection{Statistical analyses}

In order to test the reduction of survival time a log-rank test was performed. Thiosulphate, succinate and amino acid concentrations were tested for statistical signifi- 


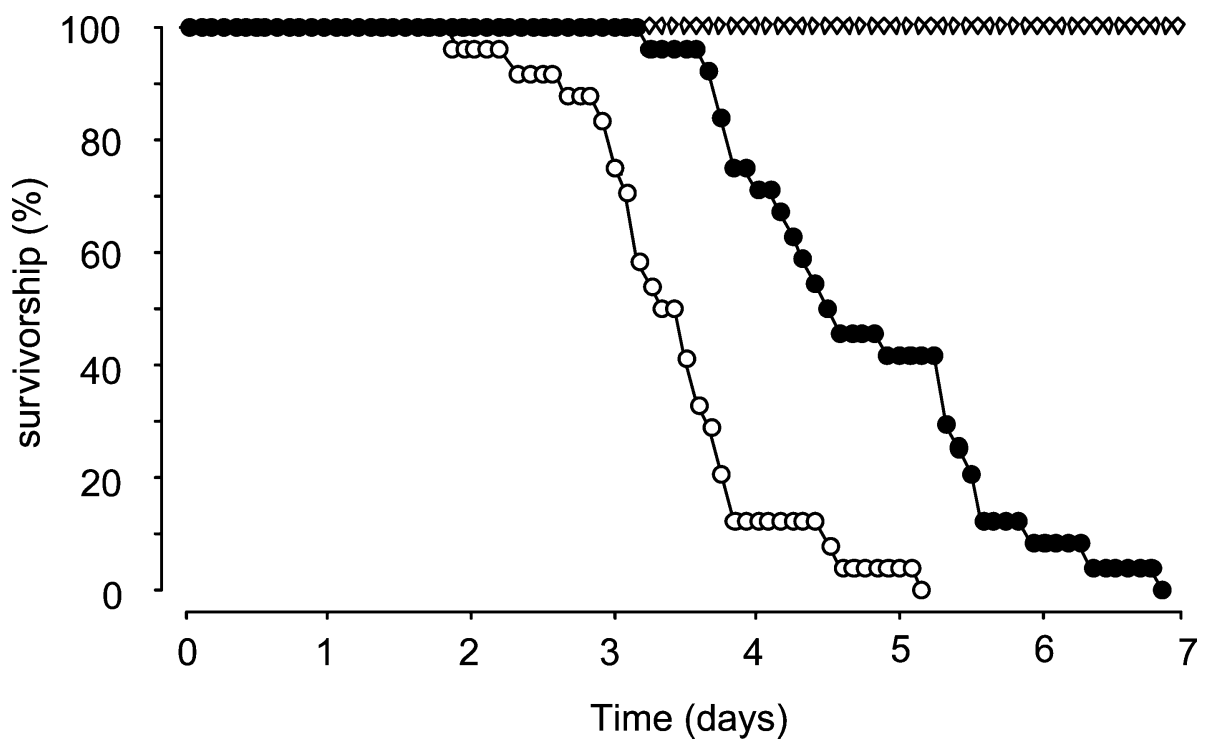

Fig. 2. Percentage of surviving post-settled D. serra during severe hypoxia in the absence (solid circles) or presence (open circles) of sulphide. Normoxic controls are shown as rhombi. $N=24$ per treatment.

cance using ANOVA at the 5\% level. Prior to the test, data of thiosulphate were squareroot transformed, data of succinate were logarithmical transformed in order to achieve normality and induce homogeneity of variances.

\section{Results}

\subsection{Experimental hypoxia}

The average oxygen concentration of the incubation water was $0.337 \mathrm{ml} \mathrm{l}^{-1}$ with very little variation between the different experimental runs and during each run $\left( \pm 0.002 \mathrm{mll}^{-1}\right.$, $n=17$ ). Sulphide levels were in the range of $100 \pm 25 \mu \mathrm{mol} 1^{-1}$. Normoxic control flasks had a constant average oxygen concentration of $10.491 \pm 0.153 \mathrm{ml} \mathrm{l}^{-1}$.

Under normoxic conditions, post-settled $D$. serra were buried in the sediment and the tips of the siphons were visible at the sediment surface. In contrast, under hypoxic conditions, test clams remained buried and the siphons extruded only for the first $2 \mathrm{~h}$ regardless of the presence or absence of sulphide. Thereafter, the clams were found lying on the sediment surface and extended their siphons into the water column. Finally, siphons collapsed and the valves gaped. When exposed to hypoxia or hydrogen sulphide, survivorship was affected. Under severe hypoxia the first animals were recorded dead

Fig. 3. Juvenile D. serra: content of thiosulphate (a), succinate (b), alanine (c) and glutamate (d) after hypoxic incubation $(0-48 \mathrm{~h})$ in the presence of hydrogen sulphide $(100 \mu \mathrm{mol} 1)$. Mean \pm S.E., $n=3$, *: significantly different from previous value; +: significantly different from control. 


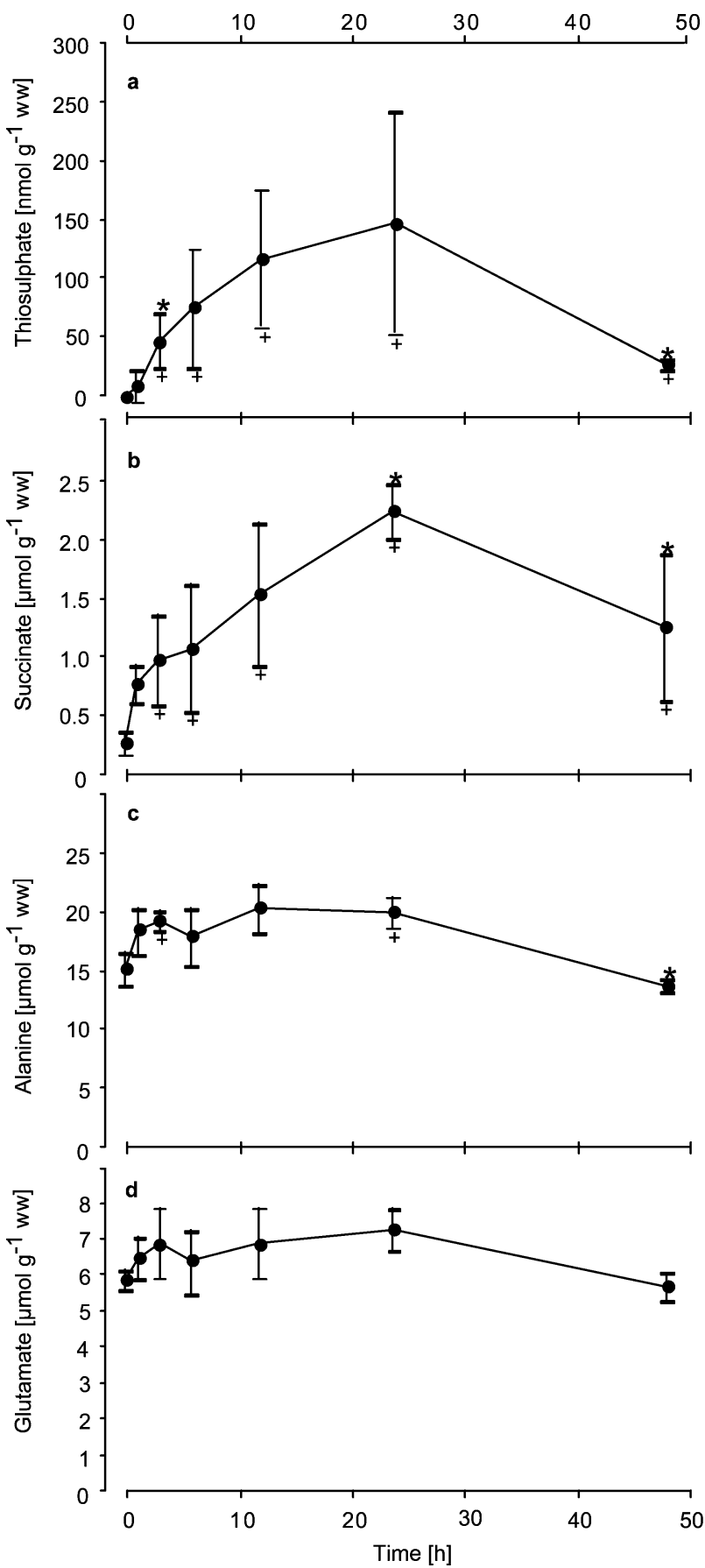


after $78 \mathrm{~h}$ with $110 \mathrm{~h}$ as a median survival time ( $\left.\mathrm{LT}_{50}\right)$ (Fig. 2). The presence of sulphide $\left(100 \mu \mathrm{mol}^{-1}\right)$ significantly reduced the survival time even further (log-rank test, $z=-4.07, p<0.01)$. The first animal died after $46 \mathrm{~h}$ and an $\mathrm{LT}_{50}$ of $80 \mathrm{~h}$ was calculated. All surf clams kept under normoxic conditions were still alive when the experiment was terminated after $200 \mathrm{~h}$.

\subsection{Sulphur compounds in the tissue}

The time course of sulphide uptake in the soft tissue was followed during $48 \mathrm{~h}$ of sulphide exposure $\left(100 \mu \mathrm{mol} 1^{-1}\right)$. Sulphide itself was not detectable in the soft tissue and sulphite was only found in low concentrations $\left(0.015 \mu \mathrm{mol} \mathrm{g}^{-1}\right.$ wet mass $)$ in some specimens. Thiosulphate was the only sulphur compound that clearly accumulated, reaching a maximum of $0.148 \mu \mathrm{mol} \mathrm{g}^{-1}$ wet mass after $24 \mathrm{~h}$ (Fig. 3a), while cystein was recorded at constant concentrations $\left(0.25 \mu \mathrm{mol} \mathrm{g}^{-1}\right.$ wet mass).

\subsection{Anaerobic energy production under sulphide exposure}

The concentrations of metabolites resulting from anaerobic energy production were followed over the same time course $(48 \mathrm{~h})$. Succinate concentration increased 9-fold from the onset of exposure $\left(0.25 \mu \mathrm{mol} \mathrm{g}{ }^{-1}\right.$ wet mass $)$ to $2.23 \mu \mathrm{mol} \mathrm{g}^{-1}$ wet mass after $24 \mathrm{~h}$ (Fig. 3b). The concentration of alanine $\left(17.5 \pm 2.5 \mu \mathrm{mol} \mathrm{g}^{-1} \mathrm{wm}\right)$ was significantly elevated after 3 and $24 \mathrm{~h}$ (ANOVA, $p<0.05$ ), while it decreased significantly between 24 and $48 \mathrm{~h}$ (ANOVA, $p<0.05)$. Glutamate levels $\left(6.5 \pm 0.8 \mu \mathrm{mol} \mathrm{g}^{-1} \mathrm{wm}\right)$ did not change significantly during the experiment (ANOVA, $p>0.05$; Fig. $3 \mathrm{~d}$ ) and aspartate was not detectable.

\section{Discussion}

Marine invertebrates inhabiting coastal zones with sporadical hydrogen sulphide occurrence such as the central Namibian coastal upwelling system use a variety of behavioural, biochemical and physiological traits to either avoid the contact or to withstand this poisonous substance. The epibenthic blue mussel, Mytilus edulis, for instance closes the shells as a passive protection against the poisonous effects of hydrogen sulphide (Jørgensen, 1980). A similar behaviour has been observed for Perna perna (Schiedek and Currie, unpublished data). The studied juvenile D. serra, however, were observed lying on the sediment surface with siphons extended into the water column when exposed to hypoxia or sulphidic hypoxia. This is in agreement with observations from other infauna bivalves during experimental (Mulinia lateralis: Shumway et al., 1983; Abra alba: Rosenberg et al., 1991; Scrobicularia plana: Oeschger and Pedersen, 1994) and field studies (Mya arenaria, Cerastoderma edule and A. alba: Jørgensen, 1980). Deposit feeding bivalves, such as $D$. serra, use their siphons to take up organic particles by filtering the water. The observed permanent siphon extrusion in the presence of sulphide may reflect a strategy to monitor the water for better conditions and might not be coupled with high ventilation activity. The clam $S$. plana, for instance, reduced ventilatory water 
flow under exposure to keep the sulphide concentration low in their extrapallial fluid. In addition, a diffusive barrier against sulphide might exist in the siphons (Oeschger and Pedersen, 1994).

The observed migration of $D$. serra to the sediment surface during hypoxic sulphide exposure appears to be an adaptation to the specific conditions prevailing in such kind of coastal systems. Natural "sulphide eruptions" within the Benguela upwelling system often affect restricted surface areas of some $100 \mathrm{~m}^{2}$ only (Currie, 1999; personal observation). Therefore, moving to the sediment surface favours the transport with currents to other areas where the mobile clams might find better conditions. On the other hand the clams have to cope with dangers like (i) a possible wash up followed by mortality due to overheating in the sun or predation by seagulls (McLachlan et al., 1980; J. Laudien, unpublished data); and/or (ii) a constant exposure to pelagic and epibenthic predators, able to enter the toxic water body while feeding (Phil et al., 1992). The advantages of being transported to more favourable conditions seem to compensate for these disadvantages.

As mentioned above, marine invertebrates regularly exposed to hydrogen sulphide have acquired a variety of biochemical adaptations to eliminate this poisonous compound (reviews: Vismann, 1991b; Bagarinao, 1992; Völkel and Grieshaber, 1995; Grieshaber and Völkel, 1998). The detoxification of sulphur compounds to less or non-toxic oxidation products is known to be a common strategy in marine bivalves (Cary et al., 1989; O'Brien and Vetter, 1990) and other invertebrates (Vismann, 1991a; Völkel and Grieshaber, 1995). In $D$. serra, thiosulphate appears to be the main product of mitochondrial sulphide oxidation, as it was the only detoxification product found at elevated amounts after experimental sulphide exposure. Thiosulphate accumulated from the onset of exposure to a maximum of $0.148 \mu \mathrm{mol} \mathrm{g}^{-1}$ wet mass (wm) after $24 \mathrm{~h}$. This demonstrates that oxygen stored in body fluids and/or oxygen remains in the incubation water $\left(<0.3 \mathrm{ml} \mathrm{l}^{-1}\right.$, due to the remaining oxygen in the nitrogen gas corresponding to the purity grade noted in the techsheet) seems to be still available for oxidative processes. Thiosulphate is almost nontoxic (Voegtlin et al., 1924; Sörbo, 1972), not inhibiting oxidative metabolism (Vetter et al., 1989) and highly soluble. The detected value is in the same range as found in the Baltic clam Macoma balthica $\left(0.177 \mu \mathrm{mol} \mathrm{g}^{-1} \mathrm{wm}\right.$, Jahn and Theede, 1997) but lower than concentrations seen in other marine invertebrates (Marenzelleria $\mathrm{cf}$. wireni: $1 \mu \mathrm{mol} \mathrm{g}$ wm, Schiedek et al., 1997; Arenicola marina $30 \mu \mathrm{mol} \mathrm{g}{ }^{-1}$ wm, Grieshaber et al., 1995; Hediste diversicolor: $100 \mu \mathrm{mol} \mathrm{g}^{-1} \mathrm{dm}$, Hahlbeck et al., 2000).

The observed decrease of the thiosulphate concentration in the soft tissue of $D$. serra after $24 \mathrm{~h}$ may be explained with a decreasing oxygen tension in the tissue. As thiosulphate is highly soluble it can, therefore, not be accumulated to infinite concentrations within tissues. Grieshaber and Völkel (1998) concluded that it is generally not further metabolised but eliminated by outward diffusion. Accordingly, no thiosulphate transport system could be identified in invertebrates (Hauschild et al., 1999).

It is remarkable, that no sulphide could be detected in the clams' soft tissue after exposure to sulphide. This leads to the assumption that sulphide detoxification is very efficient allowing the clams to maintain a very low sulphide level for a period of about $24 \mathrm{~h}$ when exposed to $0.1 \mathrm{mmol}^{-1}$ hydrogen sulphide. This level represents concentrations measured in the coastal area off Namibia during sulphide eruption events (A. van der Plas, personal communication). These findings further support that juvenile $D$. serra are able to 
deal with hydrogen sulphide for a short period, giving them the opportunity to move to a more suitable location as described above.

Many euryoxic marine bivalves and other invertebrates use alternative pathways of anaerobic energy production for long-term hypoxic survival (e.g., Storey and Storey, 1990; De Zwaan, 1991; Grieshaber et al., 1994). One predominant anaerobic product is succinate, which accumulates in the tissue (e.g., Kluytmans et al., 1977; Widdows et al., 1979; Kluytmans and Zandee, 1983; Demers and Guderley, 1994; Sukhotin and Pörtner, 1999). The present results support these findings: when exposed to sulphidic hypoxia, post-settled $D$. serra switched to anaerobiosis - which resulted in a 9-fold increase of succinate levels. Starting from relatively high levels, alanine accumulated to an even higher extent. For intertidal species, this might be a regular event, since they must switch to anaerobiosis during low tide when the substratum is exposed to air and the penetration of oxygen into the sediment is not sufficient to support fully aerobic energy production (reviews: Schöttler and Bennet, 1991; Grieshaber et al., 1994). Cockcroft (1990) stresses that anaerobic metabolism includes a significant energy saving strategy and may even explain the obvious success of D. serra on southern African coasts.

Relying on anaerobic metabolism, however, does not provide complete protection against "sulphide eruptions". Under severe hypoxia and in the absence of sulphide, all of the juvenile $D$. serra survived for more than 4 days (LT ${ }_{50} 110$ h, Fig. 2). Under hypoxicsulphidic conditions, survivorship was significantly reduced ( $\left.\mathrm{LT}_{50} 80 \mathrm{~h}\right)$. Non-dissociated hydrogen sulphide diffuses easily through biochemical membranes (Powell, 1989; Julian and Arp, 1992) and reversibly inhibits the last enzymatic reaction of the respiratory chain by forming a stable complex with cytochrome $c$ oxidase. In the presence of sulphide, aerobic respiration is therefore impossible (Nicholls, 1975; Nicholls and Kim, 1981, 1982). In the juvenile surf clams, succinate was accumulated almost directly after the onset of hypoxic-sulphidic conditions. At the same time, thiosulphate started to increase. As pointed out earlier, this suggests that the animals used much of the remaining oxygen to detoxify the penetrating hydrogen sulphide and as a consequence switched to anaerobiosis immediately. A similar reduction in survival and a more pronounced anaerobic metabolism in the presence of hydrogen sulphide has been reported for several other marine invertebrates, e.g. the polycheate worms Arenicola marina, Nephtys homgergü or Marenzelleria cf. wireni (Völkel and Grieshaber, 1992; Arndt and Schiedek, 1997; Schiedek et al., 1997). This leads to a faster breakdown of glycogen, which is known to be the major energy resource during long-term anaerobiosis (Schöttler and Bennet, 1991) and may limit survival upon its depletion. Glycogen content was not measured in the juvenile $D$. serra because of limited amount of tissue, but their stores are likely to be lower than in the adults. A size and age related increase in glycogen content has been shown for instance for juvenile lugworms (Schiedek and Schöttler, 1990).

In terms of survival periods, juvenile $D$. serra are 3-fold more sensitive to hydrogen sulphide than adult Baltic clams Macoma balthica $\left(100 \mu \mathrm{mol} 1^{-1}, 10{ }^{\circ} \mathrm{C}\right)(\mathrm{Jahn}$ and Theede, 1997). However, some of these differences are probably due to the higher temperatures used in our experiments $\left(15^{\circ} \mathrm{C}\right)$. Furthermore, the susceptibility might not only be species related, but seems also to decrease with increasing age and size (e.g., Theora lubrica: Imabayashi, 1986, Mytilus edulis: Wang and Widdows, 1991; C. Bittkau unpublished data). Jahn et al. (1997) argued that in contrast to larger animals, small 
individuals with a higher surface-to-volume ratio are unable to detoxify hydrogen sulphide effectively enough but can only survive in sulphidic habitats due to their anaerobic capacity.

This argument leads us to postulate that not only post-settled D. serra but especially larvae may be affected even more than juveniles by hydrogen sulphide and that natural "sulphide eruptions" have to be considered as an important factor for D. serra recruitment failures.

The Namibian coastline can be separated into two zoogeographical provinces, the cool temperate southwest coast (Namaqua) and the cool temperate northwest coast (Namib) (Emanuel et al., 1992). Various explanations have been given for the differing species numbers and community structures, including the Lüderitz upwelling cell acting as a barrier to northward larval dispersal. However, some species found in the area around Lüderitz are absent in the central Namibian region and reappear further north in a small pocket at Möwe Bay (Currie, 1999). Since the northern province correlates well with the post-upwelling cell characterised by oxygen-deficient bottomwater and opal-rich deposits, Currie (1999) hypothesises that the hypoxia and hydrogen sulphide associated with the Lüderitz upwelling cell could contribute considerably as a community structuring force. Various studies confirmed the structuring effect of hydrogen sulphide (Hiroki, 1977; Diaz and Rosenberg, 1995; Gamenick et al., 1996, 1998; Jahn et al., 1997). However, adult D. serra seem to be adapted to sulphidic conditions and can therefore be abundant in the southern and the northern province. Populations seem to withstand moderate sulphide eruptions even after recruitment failures, since the adults reproduce several times during their 5-year life span (Laudien et al., in press). Further research should include larval stages as well as adult animals from different provinces to confirm a possible structuring effect of naturally occurring hydrogen sulphide in the Benguela Current upwelling system.

\section{Conclusion}

The results of the present study show that juvenile $D$. serra respond to sulphide exposure conditions by moving to the sediment surface, which favours their transport by currents to nearby areas with better conditions. Initially, the clams are well adapted to detoxify hydrogen sulphate to non-toxic thiosulphate and thus keep concentrations of the toxin at very low levels within the valves. The juvenile clams are able to gain energy by switching to anaerobiosis during exposure. However, anaerobiosis and the reduction in energy requirements only supported time-limited survival, leading to a significantly reduced survivorship after 2 days. Therefore, we postulate that natural "sulphide eruptions", especially when they have large spatial and temporal extensions, have to be considered as an important factor for recruitment failures of the surf clam D. serra.

\section{Acknowledgements}

This work formed part of a $\mathrm{PhD}$ project financed by the "Deutscher Akademischer Austauschdienst (DAAD)". The field study was supported through the Namibian- 
German co-operation by "Deutsche Gesellschaft für Technische Zusammenarbeit (GTZ)". The Namibian Ministry of Fisheries and Marine Resources kindly provided laboratory and office facilities. D. S. received funding by a grant-in-aid from the "Institut für Ostseeforschung, Warnemünde (IOW)". Thanks are also due to the scientific and technical staff of the National Information and Research Centre (NatMIRC) for their friendly and helpful support, especially to E. Klingelhoeffer and J. Botha for their assistance during monitoring. T. Hirse modified the method for the capillary electrophoresis and helped to analyse succinate. Many thanks as well to S. Schadwinkel who designed Fig. 1. [SS]

\section{References}

Arndt, C., Schiedek, D., 1997. Nephtys hombergii, a free living predator in marine sediments: energy production under environmental stress. Mar. Biol. 129, 643-650.

Arntz, W., 1981. Zonation and dynamics of macrobenthos biomass in an area stressed by oxygen deficiency. In: Barrett, G.W., Rosenberg, R. (Eds.), Stress Effects on Natural Ecosystems. Wiley, Chichester, pp. $215-225$.

Arntz, W., Tarazona, J., Gallardo, V.A., Flores, L.A., Salzwedel, H., 1991. Benthos communities in oxygen deficient shelf and upper slope areas of the Peruvian and Chilean Pacific coast, and changes caused by El Niño. In: Tyson, R.V., Pearson, T.H. (Eds.), Modern and Ancient Continental Shelf Anoxia. Geol. Soc. Spec. Publ., vol. 58. The Geological Society, London, pp. 131-154.

Bagarinao, T., 1992. Sulfide as an environmental factor and toxicant: tolerance and adaptations in aquatic organisms. Aquat. Toxicol. 24, 21-62.

Bailey, G.W., 1991. Organic carbon flux and development of oxygen deficiency on the modern Benguela continental shelf south of $22{ }^{\circ} \mathrm{S}$ : spatial and temporal variability. In: Tyson, R.V., Pearson, T.H. (Eds.), Modern and Ancient Continental Shelf Anoxia. Geol. Soc. Spec. Publ., vol. 58. The Geological Society, London, pp. 171-183.

Bailey, G.W., 1999. Severe hypoxia and its effect on marine resources in the southern Benguela upwelling system. Abstract, International Workshop on Monitoring of Anaerobic processes in the Benguela Current Ecosystem off Namibia.

Brongersma-Sanders, M., 1957. Mass mortality in the sea. In: Hedgepeth, J.W. (Ed.), Treatise on Marine Ecology and Paleoecology, vol. 1. Waverly Press, Baltimore, pp. 941-1010.

Cary, S.C., Vetter, R.D., Felbeck, H., 1989. Habitat characterization and nutritional strategies of the endosymbiont-bearing bivalve Lucinoma aequizonata. Mar. Ecol. Prog. Ser. 55, 31-45.

Cockcroft, A.C., 1990. Nitrogen excretion by the surf zone bivalves Donax serra and D. sodidus. Mar. Ecol. Prog. Ser. 60, 57-65.

Currie, B., 1999. Marine chemical processes in nearshore waters of Namibia in relation to intertidal and shallow benthic fauna. Abstract, International Workshop on Monitoring of Anaerobic Processes in the Benguela Current Ecosystem off Namibia.

Demers, A., Guderley, H., 1994. Acclimatisation to intertidal conditions modifies the physiological response to prolonged air exposure in Mytilus edulis. Mar. Biol. 118, 115-122.

De Zwaan, A., 1977. Anaerobic energy metabolism in bivalve molluscs. Oceanogr. Mar. Biol. Annu. Rev. 15, $103-187$.

De Zwaan, A., 1991. Molluscs. In: Bryant, C. (Ed.), Metazoan life without oxygen. Chapman \& Hall, London, pp. 186-217

Diaz, R.L., Rosenberg, R., 1995. Marine benthic hypoxia: a review of its ecological effects and the behavioural responses of benthic macrofauna. Oceanogr. Mar. Biol. Ann. Rev. 33, 245-303.

Emanuel, B.P., Bustamente, R.H., Branch, G.M., Eekhout, S., Odendaal, F.J., 1992. A zoogeographic and functional approach to the selection of marine reserves on the west coast of South Africa. S. Afr. J. Mar. Sci. 12, $341-354$. 
Evans, C.L., 1967. The toxicity of hydrogen sulphide and other sulphides. Q. J. Exp. Physiol. 52, 231-248.

Fonselius, S.H., 1976. Methods of seawater analysis. In: Grasshoff, K., Ehrhardt, M., Kremling, K. (Eds.), Methods of Seawater Analysis. Verlag Chemie, Weinheim, p. 317.

Fossing, H., Ferdelman, T.G., Berg, P., 2000. Sulfate reduction and methane oxidation in continental margin sediments influenced by irrigation (South-East Atlantic off Namibia). Geochim. Cosmochim. Acta 64 (5), $897-910$.

Gallardo, V.A., Klingelhoeffer, E., Arntz, W., Graco, M., 1998. First report of the bacterium Thioploca in the Benguela Ecosystem off Namibia. J. Mar. Biol. Assoc. U. K. 78, 1007-1010.

Gamenick, I., Jahn, A., Vopel, K., Giere, O., 1996. Hypoxia and sulphide as structuring factors in a macrozoobenthic community on the Baltic Sea shore: colonisation studies and tolerance experiments. Mar. Ecol. Prog. Ser. 144, $73-85$.

Gamenick, I., Abbiati, M., Giere, O., 1998. Field distribution, tolerance and general protein patterns of Capitella capitata (Annelida: Polychaeta) around shallow water hydrothermal vents off Milos (Aegean Sea). Mar. Biol. 130 (3), 447-453.

Grasshoff, K., Kremling, K., Ehrhardt, M., 1983. Methods of Seawater Analysis. Wiley-VCH Verlag, Weinheim, p. 419.

Grieshaber, M.K., Völkel, S., 1998. Animal adaptions for tolerance and exploitation of poisonous sulfide. Annu. Rev. Physiol. 60, 33-53.

Grieshaber, M.K., Hardewig, I., Kreutzer, U., Pörtner, H.-O., 1994. Physiological and metabolic responses to hypoxia in invertebrates. Rev. Physiol. Biochem. Pharmacol. 125, 44-147.

Grieshaber, M.K., Hauschild, K., Sommer, A., Völkel, S., 1995. Anaerobiosis and sulfobiosis in the lugworm, Arenicola marina L. In: Eleftheriou, A., Ansell, A.D., Smith, C.J. (Eds.), Biology and Ecology of Shallow Coastal Waters. Olsen and Olsen, Fredensborg, pp. 131-137.

Hahlbeck, E., Arndt, C., Schiedek, D., 2000. Sulphide detoxification in Hediste diversicolor and Marenzelleria viridis, two dominant polycheate worms within the shallow coastal waters of the southern Baltic Sea. Comp. Biochem. Phys. B 125, 457-471.

Hart, T.J., Currie, R.I., 1960. The Benguela Current. "Discovery“ Report 31, pp. 123-297.

Hauschild, K., Weber, W.-M., Clauss, W., Grieshaber, M.K., 1999. Excretion of thiosulphate, the main detoxification product of sulphide, by the lugworm Arenicola marina L. J. Exp. Biol. 202, 855-866.

Hiroki, K., 1977. On the resistance of isolated bivalve gill pieces to oxygen deficiency and hydrogen sulphide. Bol. Fisiol. Anim. Univ. Sao Paulo 1, 9-20.

Huxtable, R.J., 1986. Biochemistry of Sulfur. Plenum Press, New York, p. 460.

Imabayashi, H., 1986. Effect of oxygen-deficient water on the settled abundance and size composition of the bivalve Theora lubrica. B. Jpn. Soc. Sci. Fish. 5, 391-397.

Jahn, A., 1997. Ökophysiologische Untersuchungen an Macoma baltica (Bivalvia) und Cyprideis torosa (Ostracoda) über Anpassungen an den Umweltfaktor Schwefelwasserstoff. Berichte IfM Kiel Nr. 289. PhD thesis, University of Bremen, p. 130.

Jahn, A., Theede, H., 1997. Different degrees of tolerance to hydrogen sulphide in populations of Macoma balthica (Bivalvia, Tellinidae). Mar. Ecol. Prog. Ser. 154, 185-196.

Jahn, A., Gamenick, I., Theede, H., 1996. Physiological adaptations of Cyprideis torosa (Crustacea, Ostracoda) to hydrogen sulphide. Mar. Ecol. Prog. Ser. 142, 215-223.

Jahn, A., Janas, U., Theede, H., Szaniawska, A., 1997. Significance of body size in sulphide detoxification in the Baltic clam Macoma balthica (Bivalvia, Tellinidae) in the Gulf of Gdansk. Mar. Ecol. Prog. Ser. 154, 175-183.

Jørgensen, B.B., 1980. Seasonal oxygen depletion in the bottom waters of a Danish fjord and its effect on the benthic community. Oikos 34, 68-76.

Jørgensen, B.B., 1990. A thiosulfate shunt in the sulfur cycle of marine sediments. Science 249, $152-154$.

Julian, D., Arp, A.J., 1992. Sulfide permeability in the marine invertebrate Urechis caupo. J. Comp. Physiol. B. $162,59-67$.

Kluytmans, J.H., Zandee, D.I., 1983. Comparative study of the formation and excretion of anaerobic fermentation products in bivalves and gastropods. Comp. Biochem. Physiol. 75B (4), 729-732.

Kluytmans, J.H., de Bont, M.T., Janus, J., Wijsman, T.C.M., 1977. Time dependent changes and tissue specificities in the accumulation of anaerobic fermentation products in the sea mussel Mytilus edulis L. Comp. Biochem. Physiol. 58B, 81-87. 
Laudien, J., Brey, T., Arntz, W.E., in press. Reproduction and recruitment patterns of the surf clam Donax serra (Bivalvia, Donacidae) on two Namibian sandy beaches. In: Payne, A. (Ed.), Symposium 2000 - A Decade of Namibian Fisheries Science. S. Afr. J. Mar. Sci., Spec. Vol. 23.

Litchfield Jr., J.T., 1949. A method for rapid graphic solution of time-per cent effect curves. J. Pharmacol. Exp. Ther. 97, 399-408.

McLachlan, A., 1985. The ecology of two sandy beaches near Walvis Bay. Madoqua 14 (2), $155-163$.

McLachlan, A., 1986. Ecological surveys of sandy beaches on the Namib Coast. Rep. Univ. Port Elizabeth Inst. Coastal Res. 13, p. 135.

McLachlan, A., Wooldridge, T., Schramm, M., Kuhn, M., 1980. Seasonal abundance, biomass and feeding of shore birds on sandy beaches in the eastern Cape, South Africa. Ostrich 51 (1), 44-52.

Morse, J.W., Millero, F.J., Cornwell, J.C., Rickard, D., 1987. The chemistry of the hydrogen sulfide and iron sulfide systems in natural waters. Earth Sci. Rev. 24, 1-42.

National Research Council, Division of Medical Sciences, Subcommittee on hydrogen sulphide, 1979. Hydrogen sulphide. University Park Press, Baltimore, p. 183.

Nicholls, P., 1975. The effect of sulphide on cytochrome $a a_{3}$ isosteric and allosteric shifts of the reduced $\alpha$-peak. Biochim. Biophys. Acta 396, 24-35.

Nicholls, P., Kim, J.K., 1981. Oxidation of sulphide by cytochrome $a a_{3}$. Biochim. Biophys. Acta $637,312-320$.

Nicholls, P., Kim, J.K., 1982. Sulphide as an inhibitor and electron donor for the cytochrome $c$ oxidase system. Can. J. Biochem. 60, 613-623.

O'Brien, J., Vetter, R.D., 1990. Production of thiosulphate during sulphide oxidation by mitochondria of the symbiont-containing bivalve Solemya reidi. J. Exp. Biol. 149, 133-148.

Oeschger, R., Pedersen, T.F., 1994. Influence of anoxia and hydrogen sulphide on the energy metabolism of Scrobicularia plana (da Costa) (Bivalvia). J. Exp. Mar. Biol. Ecol. 184 (2), 255-268.

Poethke, W., 1973. Praktikum der Meßanalyse. Steinkopf, Dresden.

Powell, E., 1989. Oxygen, sulphide and diffusion: why thiobiotic meiofauna must be sulfide-insensitive first order respirers. J. Mar. Res. 47, 887-932.

Phil, L., Baden, S.P., Diaz, R.J., Schaffner, L.C., 1992. Hypoxia-induced structural changes in the diet of bottomfeeding fish and crustacea. Mar. Biol. 112, 349-361.

Rosenberg, R., Arntz, W.E., de Flores, E.C., Flores, L.A., Carbajal, G., Finger, I., Tarazona, J., 1983. Benthos biomass and oxygen deficiency in the upwelling system off Peru. J. Mar. Res. 41, 263-279.

Rosenberg, R., Hellman, B., Johansson, B., 1991. Hypoxic tolerance of marine benthic fauna. Mar. Ecol. Prog. Ser. 79, $127-131$.

Schiedek, D., 1997. Marenzelleria viridis (Verrill 1873) (Polychaeta) a new benthic species within European coastal waters. Some metabolic features. J. Exp. Mar. Biol. Ecol. 211 (1), 85-101.

Schiedek, D., Schöttler, U., 1990. The energy production of juvenile Arenicola marina (Polychaeta) under anoxic and hypoxic conditions. Helgol. Meeresunters. 44, 135-145.

Schiedek, D., Vogan, C., Hardege, J., Bentley, M., 1997. Marenzelleria cf. wireni (Polychaeta: Spionidae) from the Tay estuary. Metabolic response to severe hypoxia and hydrogen sulphide. Aquat. Ecol. 31, $211-222$.

Schöttler, U., Bennet, E.M., 1991. Annelids. In: Bryant, C. (Ed.), Metazoan Life Without Oxygen. Chapman \& Hall, London, pp. 165-185.

Shumway, S.E., Scott, T.M., Shick, J.M., 1983. The effects of anoxia and hydrogen sulphide on survival, activity and metabolic rate in the coot clam, Mulinia lateralis (Say). J. Exp. Mar. Biol. Ecol. 71, 135-146.

Sörbo, B., 1972. The pharmacology and toxicology of inorganic sulfur compounds. In: Senning, A. (Ed.), Sulfur in Organic and Inorganic Chemistry. Dekker, New York, pp. 143-170.

Storey, K., Storey, J., 1990. Facultative metabolic rate depression: molecular regulation and biochemical adaptation in anaerobiosis, hibernation and estivation. Q. Rev. Biol. 65, 145-174.

Sukhotin, A.A., Pörtner, H.-O., 1999. Habitat as a factor involved in the physiological response to environmental anaerobiosis of White Sea Mytilus edulis. Mar. Ecol. Prog. Ser. 84, 149-160.

Tarazona, J., Canahuire, E., Salzwedel, H., Jeri, T., Arntz, W.E., Cid, L., 1991. Macrozoobenthos in two shallow areas of the Peruvian upwelling ecosystem. In: Elliott, M., Ducrotoy, J.P. (Eds.), Estuaries and Coasts: Spatial and Temporal Intercomparisons. ECSA 19 Symposium, Amsterdam, Holland. Olsen \& Olsen, Fredensborg, pp. $251-258$.

Van der Plas, A., 1999. Monitoring of marine chemical processes in the marine environment off Namibia (1990- 
1999). Abstract, International Workshop on Monitoring of Anaerobic Processes in the Benguela Current Ecosystem off Namibia.

Vetter, R.D., Matrai, P.A., Javor, B., O’Brien, J., 1989. Reduced sulfur compounds in the marine environment. Analysis by high-performance liquid chromatography. In: Saltzman, E.S., Cooper, W.J. (Eds.), Biogenic Sulfur in the Environment. ACS Symp. Ser., vol. 393. American Chemical Society, Washington, DC, pp. 243-261.

Vismann, B., 1991a. Physiology of sulfide detoxification in the isopod Saduria (Mesidothea) entomon. Mar. Ecol. Prog. Ser. 76, 283-293.

Vismann, B., 1991b. Sulfide tolerance: physiological mechanisms and ecological implications. Ophelia 34, 1-27.

Voegtlin, C., Deyer, H.A., Leonard, C.S., 1924. On the specificity of the so called arsenic receptor in the higher animals. J. Pharmacol. Exp. Theor. 25, 297-307.

Völkel, S., Grieshaber, M.K., 1992. Mechanisms of sulphide tolerance in the peanut worm, Sipunculus nudus (Sipunculidae) and in the lugworm, Arenicola marina (Polychaeta). J. Comp. Physiol B 162, 469-477.

Völkel, S., Grieshaber, M.K., 1994. Oxygen-dependent sulfide detoxification in the lugworm Arenicola marina. Mar. Biol. 118, 137-147.

Völkel, S., Grieshaber, M.K., 1995. Sulfide tolerance in marine invertebrates. In: Heisler, N. (Ed.), Mechanisms of Systemic Regulation: Acid-Base Regulation, Ion Transfer and Metabolism. Adv. Comp. Environ. Physiol., vol. 22. Springer-Verlag, Berlin, pp. 233-257.

Wang, W.X., Widdows, J., 1991. Physiological responses of mussel larvae Mytilus edulis to environmental hypoxia and anoxia. Mar. Ecol. Prog. Ser. 70, 223-236.

Widdel, F., 1988. Microbiology and ecology of sulfate- and sulfur-reducing bacteria. In: Zehnder, A.J.B. (Ed.), Biology of Anaerobic Microorganisms. Wiley, New York, pp. 469-585.

Widdows, J., Bayne, B.L., Livingstone, D.R., Newell, R.I.E., Donkin, P., 1979. Physiological and biochemical responses of the bivalve molluscs to exposure to air. Comp. Biochem. Physiol. 62A, 301-308. 